Cahiers $d u$ MONDE RUSSE

\section{Cahiers du monde russe}

Russie - Empire russe - Union soviétique et États indépendants

$59 / 4 \mid 2018$

Varia

\title{
Amy Singleton Adams and Vera Shevzov, eds., Framing Mary
}

The Mother of God in Modern, Revolutionary, and post-Soviet Russian Culture

\section{Sonja Luehrmann}

\section{(2) OpenEdition}

12 Journals

Electronic version

URL: https://journals.openedition.org/monderusse/10900

DOI: $10.4000 /$ monderusse. 10900

ISSN: $1777-5388$

Publisher

Éditions de l'EHESS

\section{Printed version}

Date of publication: 1 October 2018

Number of pages: $715-718$

ISBN: 978-2-7132-2747-9

ISSN: $1252-6576$

\section{Electronic reference}

Sonja Luehrmann, "Amy Singleton Adams and Vera Shevzov, eds., Framing Mary", Cahiers du monde russe [Online], 59/4 | 2018, Online since 01 October 2018, connection on 08 January 2022. URL: http:// journals.openedition.org/monderusse/10900 ; DOI: https://doi.org/10.4000/monderusse.10900 
Amy SINGLETON ADAMS and Vera SHEVZOV, eds.

\section{Framing Mary}

The Mother of God in Modern, Revolutionary, and post-Soviet Russian Culture DeKalb : Northern Illinois University Press, 2018, xii + 344 p.

As a player in divine and human history, Mary the mother of Jesus has captured the imagination, loyalties, and criticism of people around the world, often acting as a reflection of wider cultural preoccupations. Amy Singleton Adams, Vera Shevzov, and their impressive cast of contributors have taken on the charge of looking at imperial Russian, Soviet, and post-Soviet culture through the lens of Marian imagery. Appropriately illustrated and assembling essays on social and cultural history, art, literature, and anthropology, the volume shows how Russians have made this Jewish woman from Palestine their own, giving her a larger-than-life role in church and society that persisted through various political and artistic revolutions.

In their introduction, the editors ably set up the field, explaining that Russia's Mary has been seen as mother more than as virgin, and spiritual intercessor 
apprehended through icons more than free-floating cultural signifier. Throughout the volume, we see the tension between assimilating Mary into cultural and artistic trends of the day and setting her apart as a timeless figure best represented through the established conventions of Byzantine iconography. Although Russian religious repertoires have been more restrictive in allowing for the kind of syncretism that produced the Virgin of Guadeloupe in Mexico or the Mary of chivalrous lore in medieval Europe, one of the major insights coming from this volume is how the image and persona of Mary participates in social and artistic shifts over the course of Russian history.

Thus, Adams and Shevzov point to the influence of select images from western Christian art, most notably Raphael's Madonna from the Sistine Chapel (11). Russia's own iconographic conventions were also transformed through technological innovations and accounts of miraculous appearances, leading to an explosion of Marian iconography on the eve of the Bolshevik revolution. The openness of Mary's image to the trends of twentieth- and twenty-first-century art remains a major point of contention, illustrating how the "wide-ranging appropriations" of this single figure continue to reflect popular and elite thinking about the boundaries of secular and sacred politics.

The individual chapters are arranged chronologically, ranging from the eighteenth to the twenty-first century. Almost all essays connect various modes and genres of representation: Elena Boeck's study of eighteenth century Mariological manuscripts shows how scribes adapted visual representations of remote places to Russian conventions even as they familiarized readers with them verbally. This finds echoes in the insightful analyses by Amy Singleton Adams on Maksim Gorkii's adaptations of Marian imagery and Alexandra's Smith's work on Mary in the writings of Silver Age poet Marina Tsvetaeva. Both authors, the interpreters find, were influenced by the visual representations of Mary that saturated their lived worlds and transposed those into texts that subtly invoked icons through description and verbal composition. By directing our attention to the many modes of representation in which Mary appears, these essays break new ground in connecting art and literary history, showing the pathways of influence and association by which Mary saturated the cultural sphere.

One major feature of Russian Mariology is that there is not one Mary, but a large number of icon types that represent her, each with their own history, specialization, and regional following. While Mary has appeared to Orthodox believers as much as to their Catholic counterparts, these appearances in the Orthodox world are often dreams of a particular icon rather than of a human figure. It is not surprising that a number of essays focus on specific icon types, such as the Akhtyrka icon, found in Belgorod diocese in the eighteenth century (Worobec) and the Oranki and Iveron icons venerated by nuns of the Convent of the Exaltation of the Cross near Nizhnii Novgorod (Wagner). Vera Shevzov's overview of Mary's place in post-Soviet culture wars discusses icon types whose recognition is under dispute, such as the image named "Rus' Resurrecting." Through the proliferation of icon types, the image of Mary is infinitely adaptable to local contexts, but her political 
and aesthetic message remains somewhat more controlled than that of a Mary of personal apparitions.

The political messages of Mary are explored for the imperial period by Sarah Pratt, who looks at Pushkin's Mary in Gavriiliada as a flirtation with western aesthetic and sexual codes that are eventually repatriated and made "quintessentially Russian" (95). For the post-Soviet period, Stella Rock gives us a view of the revival of Marian pilgrimages as a way of constructing continuity and authenticity across social disruptions, and Shevzov expertly places Mary in post-Soviet debates about artistic representation and the place of Orthodox Christianity in public life. In her portrayal, the Russian Orthodox Church is ambivalent about Mary's popularity, using it as a claim to cultural precedence, but not quite ready to allow her to be absorbed into twenty-first century culture.

A very interesting set of essays portrays the development of Marian representations during the Soviet period, across artistic genres and connecting émigré thinkers with those who remained in Russia. In line with the work of Irina Yazykova and others, here we learn that the time of Soviet anti-religious persecutions was also a time of peculiar flowering of religious art and thought. Thus, Wendy Salmond introduces readers to the work of Kuzma Petrov-Vodkin, an icon-painter turned-socialist-realist whose work continued to reflect on the meaning of Mary in the language of Soviet aesthetics. Natalia Ermolaev and Roy Robson look at émigré images of Mary in the theology of the Paris circle and the work of iconographer Pimen Sofronov, and Elizabeth Skomp considers the samizdat journal Mariia. Together, these essays show that Mary's ability to transcend secular-sacred divides persisted to some extent through the Soviet period, while she also became a catalyst for this divide. Soviet writers and artists used the resonance that Mary as a symbol retained for their audiences to create new images of Soviet motherhood, while émigré intellectuals refined the idea of a separate Eastern Mariology in part in order to distinguish themselves from what they saw as a secularized West. Encountering her as a countercultural symbol, the members of Leningrad's Mariia circle came perhaps closest to constructing a "feminist" Mary.

Together, this subset of essays addresses a key question of studies of Soviet secularism: whether it constituted a transposition of old themes of sacred legitimation into Marxist language or a radical departure from religious traditions. The answer seems to be neither, at least as far as Mary as cultural theme is concerned. Rather, at least some artists and writers looked to redeveloped religious codes for expressing themes of "co-suffering and co-participation in both the domestic and international communities" (239) and the "mysteries of motherhood" (179) that were also themes of Soviet and secular émigré discourse.

It is difficult to imagine a better line-up of authors for this volume; if there is an additional topic that could have been included, it might be views of Mary from Russia's non-Orthodox traditions. Are there Marian themes in Tatar literature, analogous to Agnes Kéféli's insightful analysis of the tale of Joseph and Sulayka as a link between Qur'anic and Biblical narratives? How does the émigré processing of the world of the shtetl address themes of motherhood outside or in contrast to a 
Marian framework? Staying within the bounds of Orthodox Christendom lends a welcome conceptual unity to the volume, but also raises curiosity about the fixity of that boundary.

Taken as a whole, the volume gives eloquent testimony to the importance and promise of attending to religious histories for constructing a cultural history of Russia. Not only is Mary everywhere, from everyday life to high politics. Following her threads also enables scholars to talk to each other across disciplinary divides and see how a single figure moves across genres and modes of expression. Aptly pointing out that Mary as unmarried young mother of a single child is often appropriated for political causes of family, companionate marriage and fertility which her life story hardly supports, these essays are most effective at showing that the range of possible appropriations of religious heritage, while theoretically endless, also depends on concrete communities of skill and practice.

Sonja Luehrmann

Simon Fraser University 